\title{
The Concept of Happiness of the Malay Hero Hang Tuah
}

\author{
R.Hamdan \\ Department of Malay Language \\ Faculty of Modern Languages and Communication, \\ Universiti Putra Malaysia \\ 43400 UPM Serdang, Selangor, Malaysia \\ rahimahh@upm.edu.my
}

\author{
S.B.Md.Radzi \\ School of Malay Language, Literature and Culture Studies \\ Faculty of Social Sciences and Humanities \\ 43600 UKM Bangi, Selangor, Malaysia \\ sbmr@ukm.my
}

\begin{abstract}
Hang Tuah is a Malay hero who is traditionally portrayed as someone who pledges his loyalty solely to his king. When Malacca was defeated by the Portuguese in the 1511, the fall of their great empire sent the heart, mind and soul of the Malays into disarray to such an extent that it had enthused the writing of the Hikayat Hang Tuah in the $18^{\text {th }}$ century purportedly to reclaim and empower a sense of Malay nationalism. It allows the rebuilding of the Malays' weakened sense of national identity due to the devastating impact of Portuguese colonialisation of the sultanate around the character of Hang Tuah. A closer examination of the Hikayat Hang Tuah however, suggests that the main purpose of the hero's struggle is for the salvation of the Islamic faith from a nation that appeared to have alienated its own religion. Interestingly, Hang Tuah left the palace and his responsibility as the admiral (Laksamana) seemingly after finding eternal happiness at the end of the text. Thus, this paper attempts to explore whether or not the 'element of happiness' that Hang Tuah had found is the ultimate form of happiness that identifies him as an Islamic Malay hero. Grounded by Syed Naquib alAttas' concept of Islamic (psychological and spiritual) happiness, this paper will analyze the element of happiness of characterized by the iconic Malay warrior and its relevance for the new generation of Muslim Malays today.
\end{abstract}

Keywords: happiness; hero; Malays; origin; Islamic perspectives

\section{INTRODUCTION}

Happiness is essential to all human beings as it can trigger the quality of life. Its definitions vary and are related to the geography, culture and religion of the society [1]. For the Muslims, their true happiness in this worldly life is directly connected to their lives in the hereafter [2]. As for the Muslim Malays in the Malay Archipelago (circa $15^{\text {th }}-16^{\text {th }}$ century), their sense of happiness is achieved by demonstrating their loyalty in serving their king as shown rather splendidly by their hero Hang Tuah. It appears that the fall of the Malaccan Empire to Portuguese (1511 A.D.) and Netherlands (1641 A.D) has compelled the Malay intelligentsia to write a manuscript, the Hikayat Hang Tuah (The Tale of Hang Tuah), that is imbued with the ideological desire to reclaim, restore and uphold the greatness, strength and dignity of Malay sovereignty [3-11]. Indeed, Hang Tuah became the ideal portrayal of a virtuous role model for his nation. Notwithstanding, Hang Tuah did not share similar fate as other world heroes like Gilgamesh (of the Sumerian epic), Beowulf (of the Anglo-Saxon epic) and Ramayana (of the Indian epic) who were destined to end their lives as proud and gallant heroes. For just when the nation needed his service to defend the land against Portuguese intrusion, Hang Tuah was unexpectedly whisked away from the palace into hiding and relieved from further duty as the Malaccan admiral (Laksamana) in anticipation of a coup to frame him by covetous warlords. That there has been a hypothesis that Hang Tuah had remained an unhappy Muslim Malay man for the most part of his life now seriously begs some rethinking and questioning, for instance, 'What is the meaning of happiness for Hang Tuah?' and 'Did he find the eternal happiness which he was searching for?'. Thus, based on the Islamic perspective of happiness of Syed Naquib al-Attas [2], this paper seeks to determine and analyse the notion of 'happiness' in Hang Tuah's life as inscribed in the Hikayat Hang Tuah (The Tale of Hang Tuah)[4].

\section{Syed NAQUiB AL-ATTAS' PERSPECTIVE OF ISLAMIC HAPPINESS}

There are many definitions by Western scholars on the idea of human happiness. Happiness or 'subjective well-being' (SWB) is a balance between positive and negative elements in human beings. [1,12]. There are two types of happiness: one is the experience of excitement attained during young; the other is the experience of peacefulness attained at a mature age [13]. However, in the Western perspective, happiness is both defined by the Aristotlelian hedonic and eudemonic aspects $[1,14]$. Hedonic aspect connects to hedonism which emphasizes pleasure (desire) as the highest achievement of emotions in human life. Thus, all human beings should try to obtain it as much as possible. Meanwhile, eudemonic pertains to an aspect happiness that is essential for the maintenance of good values, skills and positive functions $[1,14]$. The notable Muslim scholar Syed Naquib al-Attas [14] mentions that in the Western world, the notion of happiness has been dominated by secular ideology comprising moral and political issues. In fact, happiness is not an ethical value in the Western world because as described by al-Attas, 'the modern conception of happiness assess happiness as same as pagan societies)[15].

Apparently, the concept of happiness in Western Culture does not include the spiritual aspect compared to the Islamic 
perspective which pays attention to achieving balance between material and spiritual entities in pursuing happiness [14]. Western societies tend to associate religion as a cultural element whilst its value to be determined by the process of modernization. Conversely, the notion of happiness in Islam is defined or influenced by social or cultural factors [14-17]. Happiness in Islam means that a Muslim should embrace his relationship with God as it will brings the peace of minds, souls and the harmony in life [14-17]. It is not determined by material wealth, but the clarity and sincerity of the soul towards God as the very meaning Islam is submission to God [16].

Syed Naquib al-Attas [14] states that there are two aspects in Islam which brings together the happiness inside humans, for example, the knowledge and its practice based on Holy Quran and al-Hadith. Instead, to know the love of God will bring human beings closer to the happiness itself. Knowledge and good virtue will describe the spiritual elements as written in the Holy Quran [17] as soul (qalb), body (nafs), mind (aql) and spirit (ruh). These elements of happiness will vary according to situation for instance, if it relates to cognition, it is 'intellectual'; if it is the body, it is called 'physical'; if it is feelings, it is 'soul' and if it is abstract in nature, it is 'spiritual' [14].

The second aspect that leads to happiness in human life is the gaining of virtue (good personality)[14]. Every action by human beings should be directed by logical reasoning and guided by religious tenets because only then that a good invaluable character or personality can be developed through learning, training and blessings from God. Human personality may change from good to bad or evil and vice versa in the pursuit to seek eternal happiness in this world and the hereafter. That is the reality of eternal happiness pursued by every Muslim - it is not limited to happiness in this worldly life alone. Since 'sa'ädah' (the ultimate happiness) will be rewarded on the day of Judgment, Islam needs to connect the two dimensions life, that is, life before death (dunyawiyyah) and life after death (ukhrawiyyah) [14,17]. Islam places an emphasis on the worldly life (dunya) as temporary because life after death is certain and permanent. It does not mean that people need to waste this life (dunya) in order to secure the hereafter. Al-Qur'an itself has given us guidance on the meaning of 'happiness' for Muslims who must achieve 'alfalah' or well-being or success which comes through of speaking truth and good deeds [17]. Therefore, to obtain this success, a believer must able to identify with his Maker (alKhaliq). Al-Attas [14] states three phases of happiness in Islam as the following:

1. Psychological (only on worldly life and can be categorized as emotional and feelings gained by believing and desiring through positive values).

2. 'Spiritual' (permanent in nature, experience it consciously, the basis of a temporary worldly life, the assessment of the behaviour and activities which can lead to identifying the pure knowledge of Allah swt .

The second stage (spiritual) is obtained in relation to the first level (psychological). Moreover, the second stage is the marks the highest satisfaction in the form of 'worship' in describing the love of Allah in preparation for obtaining a third level, the 'Vision of God'. Vision of God' is arguably the right path to know Allah swt (ukhrawi).

Hang Tuah's character in the Hikayat Hang Tuah (The Tale of Hang Tuah) [4] is also synonymous with the symbol of Malay dominance. Malay nationalists are also inspired perhaps by the slogan 'Malays will not vanquish from this world' by the nationalist of $20^{\text {th }}$ century post-colonial in order to re-unite and strengthen the identity among the Malays.

\section{HAPPINESS FOR A MALAY HERO}

A 'Hero' is not born but formed by the inherited tradition of human society. All Malay 'Heroes' assume certain roles and functions in Malay societies [18]. There are many heroes found in Malay literature in works like Hikayat Seri Rama, Hikayat Amir Hamzah, Hikayat Muhammad Hanafiah, Hikayat Saif Dhu'l-Yazan (or Saiful Lizan), Hikayat Sama'un and Hikayat Raja Handak (or Khandak). However, Hang Tuah remains the only hero whose character successfully captures the essence and history of the 15th century Malaccan kingdom and its Malay ruler which consequently allow for the Malays to propagate their purported noble origin and superior status against all other human beings in the land [19] as stated by Farish A.Noor [11]:

"[...] one cannot imagine a nation without a common corpus of legends and lore, a common depository of the collective wishes and aspirations of the community set to poetry or prose. [...] Nations need tales, epics and fables to glue them together, and to give the members of such nations a common compass, a heading, a beacon to follow and admire'.

On closer examination of the Hikayat Hang Tuah (The Tale of Hang Tuah) [4], there are many episodes illustrating the grandeur of this Malay hero. However, despite his greatness, Hang Tuah was disappointing during his nation's hour of need by abandoning all hopes, responsibility and obedience to the ruler of Malacca who had to defend the city from Portuguese attack. Based on Hang Tuah's own actions, it can be assumed that he was bereft of the ultimate satisfaction and happiness throughout his life as the greatest warrior of Malacca. This is evident especially when he was willing to be the leader of the Aboriginal tribes of the Perak interior forest. Applying al-Attas' perspective of happiness in Islam [14] has certainly been useful in justifying the contradiction in the life of this Malay hero.

\section{A. Physcological Happiness (Human Emotion and Feeling)}

Syed Naquib al-Attas [14] states that psychological happiness is attained through the formation of moral values. As for the traditional Malays, their happiness in this worldly life is directly achieved by showing their loyalty to the monarchy. The happiness of the King reflects the happiness of the people. In Hikayat Hang Tuah (The Tale of Hang Tuah) [4], there are several episodes describing Hang Tuah's psychological happiness. Hang Tuah's devotion to the palace as a Malay warrior was very important in stabilizing the relationship between King and People. In the preliminary of Hikayat Hang Tuah (The Tale of Hang Tuah)[4], it is stated that he, is very loyal to his master and he is willing to die for 
him, ' [4]. It shows the perception that obedience to one's King was desirable for the overall well-being and happiness for the Malays. An example of such happiness can be seen when Hang Tuah and his pack of loyal friends (Hang Jebat, Hang Kasturi, Hang Lekir, Hang Lekiu) trounced a man who had run amok and tried to harm the Malaccan Bendahara (Prime Minister). This incident marked the turning point in Hang Tuah's life which was also significant in teaching him how the notion of happiness was related to serving the king and the nation as their defender and protector [4].

Hang Tuah's happiness can be seen when he was given the honour to escort the sultan's envoy to Majapahit. Hang Tuah successfully enhanced the dignity of the Sultan of Malacca following his duel with the Majapahit hero (Taming Sari) whose defeat saw his famous and powerful dagger (keris) fall into the Malaccan hero's hand. Hang Tuah's happiness was seen when he managed to ensure the entourage return safely to Malacca. In another scenario, he found contentment when he was able to tame a wild horse that belonged to the king because nobody could accomplish this dangerous task before. The King's happiness was paramount for Hang Tuah, and this now becomes an important factor to achieve his own happiness as the hero of Malacca [4].

It was crucial for Hang Tuah's sense of happiness if he could be an effective international diplomat to the world in order to strengthen the relationship between Malacca and foreign countries [4] like India, China, Thailand, Ceylon and Rome. Hang Tuah would demonstrate the greatness of the king of Malacca to the world by observing his duties as King's loyal admiral (Laksamana) overseas. In short, only the happiness of his Highness that can bestow upon Hang Tuah his own personal satisfaction.

\section{B. Spiritual Happiness}

Interestingly, Hang Tuah's spiritual happiness has not been prominently displayed in the Hikayat Hang Tuah (The Tale of Hang Tuah)[4]. It only describes his spiritual experience when he performed the hajj in the Holy Land whilst en-route to Rome (Turkey) as the recipient of sophisticated weaponry to be used in battles against the Portuguese. The text describes his spiritual happiness as the process of purification of the soul during his stay in Mecca for, although not clearly stated, there is an insinuation of the presence of a spiritual connection between a man (Hang Tuah) and his Maker. Indeed, Hang Tuah's adventure to Egypt can also be regarded as a spiritual journey for him for he was truly inspired and gracious with amazement of God's creative powers especially the scenery along the historic Nile River. But arguably, the ultimate spiritual adventure in Hang Tuah's life must have been his descend into a grave's upon the King's order. With this experience, Hang Tuah discovered the genuine happiness he had been looking for in his life and there was nothing better for him to meditate and contemplate his identity and that of his Creator than to do it in a six-feet deep chamber inside the cold smelly earth. For Hang Tuah had finally realized that he would only further prolong his ignorance and blind loyalty if he had continued to serve his King instead of his Maker. Thus, he decidedly estranged himself at Jugra Hill to learn about Islam from a sheikh (mullah) from Gujarati and hence, found the ultimate happiness.

\section{Hang Tuah as the HERO: The Balance of HAPPINESS IN ISLAM}

Al-Attas [14] argues that according to Islamic perspective happiness (Sa'adah) connects two worlds, the worldly life (dunyawiyyah) and Hereafter (ukhrawiyyah). However, for a Malay hero like Hang Tuah happiness may only be achieved by showing his loyalty as a servant to the king, in discharging his duties as Admiral and diplomatic functions to promote the glory of Malacca to the world. They all but signify only psychological happiness for Hang Tuah, not the true happiness (spiritual) guaranteed by his religion in the hereafter. Indeed, Hang Tuah once lived in a social and political environment whereby the king was viewed as the supreme ruler, an image of Almighty God and the Caliph of Allah worthy of the respect and obedience of his subjects. Historically, the traditional convention of the time regards the King's sovereignty as defined by the loyalty of his national subjects, not by his faith. In fact, the traditional ethics upheld by the Malays are as below:

1. The government or the court has the sole authority to determine what is good or bad (since ethics is something that relativistic and non-objective)

2. Muslim congregational members may or may not be requested for their advice if they are present within the palace.

3. The actions of the ruling class cannot be questioned. This happens due to waadat or agreement between the ruler (the king) and ruled (people).

4. The warrior's dependability or military strength is determined by who is right and who is wrong because often leading warriors perform a symbolic fight between two kingdoms or dynasties.

5. The reference to God's law or Islamic religious guidelines are not made at the beginning of an action or behavior. Mostly just referring to the law of God after begging to do an act. Remorse is marked by action or abdicated as Sufis [10].

It is clear that Hang Tuah is only a heroic character to boost the self-esteem, cultural identity and a model leader for the Malay communities helplessly facing the onslaught of Western colonialism. Yet he constrained himself in treading a fine balance between seeking worldly and spiritual (duniawi and $u k h r a w i$ ) happiness. In the end, Hang Tuah found his true happiness after relinquishing his office to begin his exilic life ironically, among the aborigines, in order to re-learn about his religion, God and himself. The author of Hikayat Hang Tuah (The Tale of Hang Tuah) [4] seems to convey his disappointment by punishing the Malay hero for the fall of Malacca to the Portuguese by alienating him to the lowest strata of Malay society. 


\section{CONCLUSION}

By using al-Attas perspective of happiness in Islam, we have revealed that Hang Tuah did not find the balance in search of happiness in his life. The examination the Hikayat Hang Tuah (The Tale of Hang Tuah) [4] suggests that Hang Tuah initially achieved psychological happiness rather than spiritual happiness. He realized, however, that psychological happiness would not enable him to fully recognize Almighty God as his Creator. This realization forced him to forget worldly matters (dunya) as such including the critical moment of the Portuguese invasion of Malacca in 1511 A.D. It was living a life in isolation on Jugra Hill that had finally brought Hang Tuah to discover eternal happiness which he would cherish for the rest of his life. Living as head of aborigines communities in the quiet and peaceful Perak hinterland helped Hang Tuah to attune to his new and a more balanced perspective of both worlds (duniawi and ukhrawi).

Therefore, we believe that it is now time to consider Hang Tuah as a Malay hero par excellence for social transformation of the 21 st century generation of Muslim Malays. Firstly, there is a lack of Islamic elements applied by the author onto the hero's life despite Islam being synonymous with the Malays $[2,14]$. Secondly, a hero needs to be a Muslim-Malay role model from the beginning until the end of the narrative where for instance, Islamic epic heroes like Amir Hamzah (Hikayat Amir Hamzah) and Muhammad Hanafiyyah (Hikayat Muhammad Hanafiyyah) attempted to utilize and mobilize Islam as the main purpose of their struggles. Thirdly, the hero's psychological and spiritual happiness is imbalanced and his celebrated existence should not have been unceremoniously displaced by a hermetic life amongst the aborigines - whose people are depicted as uncivilized primitive society and deemed fit for slavery as informed by W.E. Maxwell in his book Law Relating to Slavery which $19^{\text {th }}$ century slavery of the aborigines by Malays. [20]. And finally, it is not appropriate for a Malay hero to be humiliated and which caused aspersion to be cast upon his character for this may only generate confusion on the new generation of Muslim Malays. Finally, the Malay hero Hang Tuah's narrative should be revised simply because it represents the sovereignty and identity of the Malays and this country.

\section{ACKNOWLEDGMENT}

Special thanks to the Research University Grant Scheme (RUGS) provided by Universiti Putra Malaysia, Serdang, Malaysia for the funding of this research.

\section{REFERENCES}

[1] Joshanloo,M. A Comparison of Western and Islamic Conceptions of Happiness. Journal of Happiness Studies : An Interdisciplinary Forum on Subjective Well-Being. Retrieved 27 May 2013, from http;//link.springer.com/article/10.1007/s10902-012-94067/fulltext.html), 2012.

[2] Al-Attas, Syed Muhammad Naquib. Islam dalam Sejarah dan Kebudayaan Melayu. Kuala Lumpur: Universiti Kebangsaan Malaysia., 1972.

[3] Parnickel.B. An Epic Hero and An Epic Traitor in the Hikayat Hang Tuah, Bijdragen tot de Taal-, Land en Volkenkunde, 132: 403-417, 1976.
[4] Kassim Ahmad (pngr.). Hikayat Hang Tuah. Kuala Lumpur: Yayasan Karyawan dan Dewan Bahasa dan Pustaka, 1997.

[5] Josselin de Jong. The Rise and Decline of A National Hero, Journal of the Malaysian Branch of the Royal Asiatic Society 38 (2): 140-155, 1965.

[6] Teuuw.A.Tentang Penghargaan dan Penafsiran Hikayat Hang Tuah, Dewan Bahasa (8):339-354, 1965.

[7] Muhammad Hj.Salleh. Central Values of the Malay Hero Hang Tuah. Tenggara 17/18:74-97, 1983

[8] Shaharuddin Maaruf. Concept of A Hero in Malay Society. Singapore: Eastern Universities Press, 1984.

[9] Braginsky, V.I. Hikayat Hang Tuah: Malay Epic and Muslim Mirror: Some Consideration on its Date, Meaning and Structure, Bijdragen tot de Taal-, Land en Volkenkunde, 146 (4):399-412, 1990.

[10] M.Khalid Taib. Konsep dan Kedudukan Wira dalam Teks Melayu Klasik Terpilih: Satu Tinjauan dari Sudut Etika Sezaman dan Universal. Dlm. Konsep Wira dalam Sastera Melayu. Siti Aisah Murad (pnyt.), 129. Kuala Lumpur: Dewan Bahasa dan Pustaka, 1993.

[11] Farish Noor. What Your Teacher Didn't Tell You. The Annexe Lectures, Vol.I, Petaling Jaya: Matahari Books, 2009.

[12] Diener, E. Subjective Well-Being, Psychological Bulletin (95): 542-575, 1984.

[13] Barret, L.F., Niedenthal, P.M. and Winkielman, P.(eds.). Emotions and Consciousness. New York: The Guilford Press, 2005.

[14] Al-Attas, Syed Muhammad Naquib. The Meaning and Experience of Happiness in Islam. Kuala Lumpur: ISTAC, 1993.

[15] Amer Al-Roubaie. 'Al-Attas Concept of Happiness: A Reflection on the Contemporary Meaning of Development'. In, Wan Mohd.Nor Wan Daud \& Muhammad Zainiy Uthman (eds.). Knowledge, Language, Thought and The Civilization of Islam. Essays in Honor of Syed Muhammad Naquib al-Attas. Skudai: UTM, 2010.

[16] Al-Seheel, Ali Youssef. Gratitude Intervention and Happiness: An Experimental Investigation on IIUM Students. Proceeding 8th International Postgraduate Research Colloquium (IPRC) di Srinakharinwirot University, Bangkok, Thailand, 22 hingga 23 September 2011.

[17] Al-Quran (13:28)

[18] Edmonson, M.,S. Lore: An Introduction to the Science of Folklore and Literature. New York: Holt, Rinehart and Winston, Inc, 1971.

[19] Liaw Yock Fang. Sejarah Kesusasteraan Melayu Klasik. Singapura: Pustaka Nasional, 1975.

[20] Likosky, M. (ed.). Transnational Legal Processes: Globalization and Power Disparities. London: Butterworths, 2002. 